\title{
The Interpretation of Metamorphosis as a Narrative Device in George MacDonald's Fairy Tales
}

\author{
Diana Hayroyan \\ Yerevan State University
}

\begin{abstract}
The following article is an attempt to study metamorphosis as a narrative device in Scottish fairy tale writer George MacDonald's fairy tales. Due to a closer study of the theoretical background of metamorphosis and the analyses of the examples it becomes possible to describe metamorphosis not only as a stylistic but also as a narrative device. In the mentioned fairy tales metamorphosis, granting specific meaning to the events, reveals the unique poetics of the fairy tales and promotes a deeper understanding of the fairy tale text thus fulfilling the author's intention.
\end{abstract}

Key words: interpretation, fairy tale, metamorphosis, narrative device, trope.

\section{Introduction}

Mystical transmutations and metamorphic transformations are universal themes that have been the subjects of human expressions created through art, music and literature.

In its broadest sense metamorphosis is a marked change in appearance, character, condition or function as well as transformation by magic or sorcery. Metamorphosis as a tropological problem is another subject addressed in many recent studies. Many scholars, among them Tzvetan Todorov, do not accept that metamorphosis can have an autonomous rhetorical status. He considers metamorphosis to be the propensity of the text to get rid of tropes, a tendency to literalize tropes at the expense of the intentional enlivening of their worn hackneyed semantics (Todorov 1975:77-79).

Metamorphosis is widely used in fairy tales occupying its unique place among the rhetorical figures in this genre. The tropic status of metamorphosis here is of singular nature. It functions as a narrative figuration of figurative language, as linguistic events are projected into the world "out there" as narrative fictions. Thus it may take a figurative expression and spin from it a narrative fleshed out with persons, times and places. A. Jivanyan (2007) claims that metamorphosis in fairy tales is a unique trope belonging more to the story than to the rhetoric of the fairy tale. In a certain sense metamorphosis can be seen as a genre-defining device. No wonder one of the famous collections of fairy tales written by the Roman fairy tale writer Lucius Apuleius is called Metamorphosis or The Golden Ass (Jivanyan 2007:50) Thus, from a stylistic device it turns to a narrative device giving the story a powerful push forward. A unique place in this respect belongs to George MacDonald's fairy tales.

The present article touches upon the study of metamorphosis as a narrative device, its impact and interpretation in George Macdonald's fairy tale The Princess and the 
Goblin and its sequel The Princess and Curdie which are vivid patterns for employing metamorphosis as a narrative device. These fairy tales, particularly rich in metamorphosis, illuminate specific subtle nuances of metamorphosis as a narrative device which catches the reader's attention and, as a specific narrative device, fulfills the author's intention.

\section{Metamorphosis in The Princess and the Goblin}

In The Princess and the Goblin Irene's great-great grandmother becomes the central image. The metamorphosis of the heroine does not entail change of shape; instead we find a flexible trope through which the author fills the reader with an almost inevitable feeling of wonder. Metamorphosis occurs with Irene's all-wise, all-knowing, all-loving great-great grandmother who lives in a secret, mysterious place accessible only to those she chooses. She evokes a timeless mother figure that is always there when the child needs comfort or protection. As we will see her metamorphoses possess rich symbolic meaning providing the fairy tale with narrative tension. This is how princess Irene sees her for the first time:

Perhaps you will wonder how the princess could tell that the old lady was an old lady when I inform you that not only was she beautiful, but her skin was smooth and white. Her hair was combed back from her forehead and face and hung loose far down and all over her back. That is not much like an old lady-is it? Ah! But it was white almost as snow. And although her face was so smooth, her eyes looked so wise that you could not have helped seeing she must be old.

(G. MacDonald "The Princess and the Goblin" p.17)

Macdonald's detailed descriptions conjure up amazing imagery, a feeling of mystery and special effect of magical power. It is evident that great-great-grandmother has taken a kind of disguise. She is old and at the same time she is not old. Her transformation aims at intensifying her inner qualities. She is depicted spinning, an activity usually seen as an attribute of wise old woman.

The princess opened the door and entered. There was the moonlight streaming in at the window, and in the middle of the moonlight sat the old lady in her black dress with the white lace, and her silvery hair mingling with the moonlight, so that you could not have told which was which.

(G. MacDonald "The Princess and the Goblin" p.76)

As we proceed, transformation takes place with great-great-grandmother's age. MacDonald represents her in different ages. Though her hair is white as silver her face is very smooth and white, her eyes look so wise that one cannot help seeing she must be old, thus white hair signifies age and wisdom. Her metamorphosis is indeed paradoxal. She is old and young at the same time. She wears black dress, a kind of sym- 
bol which stands for her age, whereas white lace, emphasizes her youth. MacDonald interlocks her silvery hair with moonlight, thus creating a kind of perpetuity. The focus is again on hair, which changes its colour continually, giving some hints of her age. This time MacDonald equates her hair with silvery moon and this is not accidental as she appears at night as if entering the process of darkness: her face is like a moon out of a cloud. Thus, a metaphoric relation is established between her hair and silvery moon.

And when she came nearer she found that the smell of roses with which the room was filled came from the fire-roses on the hearth. Her grandmother was dressed in the loveliest pale blue velvet, over which her hair, no longer white but of a rich golden color streamed like a cataract, here falling in dull gathered heaps, there rushing away in smooth shining falls. As she looked, the hair streamed pouring down from her head and vanishing in a golden mist ere it reached the floor. It flowed from under the edge of a circle of shinning silver, set with alternated pearls and opals. On her dress was no ornament whatever, neither was there a ring on her hand, or a necklace or carcanet about her neck. Her face was that of a woman of three-and twenty.

(G. MacDonald "The Princess and the Goblin" p.96)

The following scene describes Irene's great-great-grandmother in a different appearance. To work out implications to identify the underlying meaning of metamorphosis here is not an easy task. As we see transformation occurs with her age, she seems much younger though she still doesn't lack wisdom. The black dress changes into blue velvet witnessing that she is younger than before, the blue colour evoking a feeling of eternity and calmness. MacDonald portrays her room in blue too with the interference of blue sky with the stars shining in it. If in the previous passage her silver hair mingled with the silvery moon, now her dress of blue velvet matches the blue sky. We can see the unlimited power of the author in demonstrating his creative imagination. Now great-great grandmother's hair is of rich gold colour; it is like a stream of cataract, the shining beauty of nature that is gentle, pure and invincible. Metamorphosis of her hair colour can be viewed as an extension of simile; her hair bears resemblance to precious gold. Her old age means strength and beauty, mirth and courage. The soft moonlight and the milkiest pearl bring the child to the wonderful world of dreams and fairyland.

\section{Metamorphosis in The Princess and Curdie}

MacDonald takes up the theme of metamorphosis in the next fairy tale The Princess and Curdie which is the sequel of the previous one. Here the central image is again princess Irene's great-great grandmother. In this fairy tale Irene's great-great grandmother appears to a brave miner's son Curdie who had once helped Irene. This is how Curdie first meets Irene's great-great-grandmother: 
In the shadow on the other side of the moonlight which came like a river between, he saw the form to which the hands belonged: a small, withered creature, so old that no age would have seemed too great to write under her picture, seated on a stool beyond the spinning wheel.... She sat crumpled together; a filmy thing that it seemed a puff would blow away, more like the body of a fly. Her grey hair mixed with the moonlight so that he could not tell where the one began and the other ended. Her shoulders nearly swallowed up her head between them.... Curdie laughed within himself and when he thought of how princess used to talk about her great old grandmother he laughed more.

(G. MacDonald "The Princess and the Goblin \& the Princess and Curdie" p.9)

As has already been mentioned above great-great grandmother appears only at night, within moonlight. Now she is small, like a filmy thing. MacDonald does not portray her in a positive mood. She is not delighted and her new form wants to indicate that Curdie is in a wrong way in dealing with things as he didn't give much importance to Irene's stories about her grandmother, and she transforms herself voluntarily into a tiny creature in order to test the boy. This signifies her unnatural and magical qualities. Her hair is grey now, which shows her so-called "grey mood" and her spinning appears again as the symbol of her wisdom. MacDonald creates perfect series of similes which appear within metamorphosis.

As she spoke she held out her hand to him and when he took it she made use of his to help herself up from her stool. The same instant she stood before him a tall, strong woman-plainly very old, but as grand as she was old and only rather severe looking. Her hair was very white but it hung about her head in great plenty and shone like silver in the moonlight.

(G. MacDonald "The Princess and the Goblin \& the Princess and

Curdie" p.12)

MacDonald again presents a set of contradictions. The understanding and the interpretation of metamorphoses portrayed in the fairy tale become a complicated task. They unfold to reveal great-great grandmother's character. Now she is a tall, strong woman. The transformation is centered about her hair which in this case becomes white symbolizing her age. Her grey hair changes into white which is brought into a direct contact with the moonlight. The association is fortified by the presence of a milk-white moon.

The heroine experiences her next metamorphosis in the dark cavern:

And with that the darkness of its complexion melted away and down from the face dawned out the form that belonged to it, until at last Curdie and his father beheld a lady, beautiful exceedingly dressed in some- 


\begin{abstract}
thing pale green, like velvet over which her hair fell in cataracts of a rich golden colour. It looked as if it were pouring down from her head as if vanishing in a golden vapour ere it reached the floor. It came flowing from under the edge of a coronet of gold, set with alternated pearls and emeralds. She looked about five-and twenty years.... Curdie knew somehow that the face before him was that of the old princess, Irene's great-great-grandmother.
\end{abstract}

(G. MacDonald "The Princess and the Goblin \& the Princess and

Curdie" p.19)

Now she is dressed in pale green, she is young again. Her hair becomes a significant motif, it turns to a rich golden colour, which symbolizes her divine character, and the length of her hair reaching the floor is the sign of her inner spiritual strength, her life experience and at the same time magical power. The transformations of her vivid image arouse a very strong upsurge of emotions. Metamorphosis in the fairy tale becomes really a powerful vehicle for gaining narrative tension. Thus metamorphosis becomes more attached to the story than to the fairy tale rhetoric.

The presence of emeralds and pearls carries the symbolic connotation of warmth and fiery. Emeralds appear also as a symbol of happiness and luck and signify that Curdie will have a good fortune.

He could see no sky or stars any more, but the wheel was flashing out blue-oh such lovely sky-blue light- and behind it, of course, sat the princess but whether an old woman as thin as a skeleton leaf, or a glorious lady as young as perfection he could not tell for the turning and flashing of the wheel.

(G. MacDonald "The Princess and the Goblin \& the Princess and

Curdie" p.26)

Grandmother appears behind the wheel, and now she is thin, but glorious. Her image presents a set of contradictions: she is old and at the same time she is as young as perfection. Her shape appears through dresses and what is inside her never changes. She is the embodiment of a Holy Spirit. She takes the shape of a young woman sometimes as beautiful as an angel and then she is the most dangerous of all.

\title{
Conclusion
}

As has been observed in the present paper, metamorphosis in MacDonald's fairy tales serves as a symbolic as well as a powerful narrative tool characterized by the wide use of symbolism. It appears as an individual feature of style and becomes closely linked to the story which is the product of the author's individual and pictorial imagination. Metamorphosis stands for the development of the whole fairy tale. It is particularly worth mentioning that metamorphosis is rather widely used in the above mentioned fairy tales revealing the potential of fairy tale poetics and rhetoric in a new 
light. As a narrative tool metamorphosis provides the reader with cues to interrogate meanings that the fairy tale may offer beneath the surface. These meanings, as we have seen, can either speak to the reader indirectly or may be disguised and open to varied interpretations. The close comprehension of metamorphosis provides a different and a deeper understanding of the fairy tale.

\section{References:}

1. Humphery, C. and Prichard, M. (1995) The Oxford Companion of Children's Literature. New York: OUP.

2. Jivanyan, A. (2007) The Fairy Tale as Archetext. Yerevan: Zangak-97.

3. Mikkenon, K. (1996) Theories of Metamorphosis: Metatropeto Textual Revision. // Style, Academic Journal, Vol.30 (2).

4. Todorov, T. (1975) The Fantastic: a Structural Approach to a Literary Genre. New York: Cornell University Press.

\section{Sources of Data:}

1. MacDonald, G. (1986) The Princess and the Goblin. New York: Books of Wonder, William Morrow \& Company.

2. MacDonald, G. (1990) The Princess and the Goblin \& the Princess and Curdie. New York: World Classics, OUP.

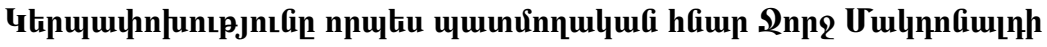 htppuptitipnú}

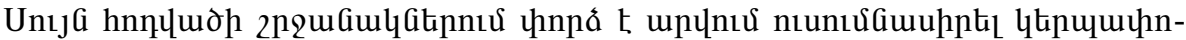

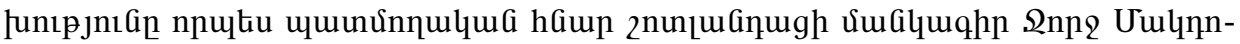

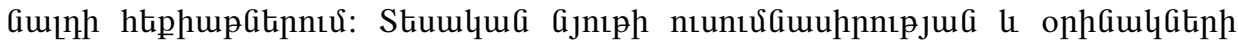

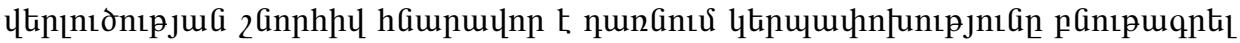

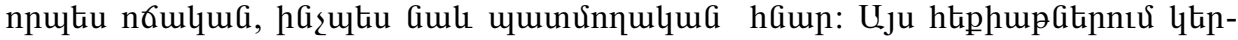

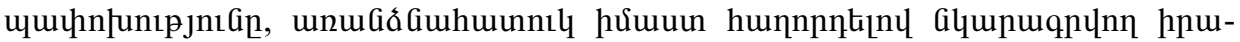

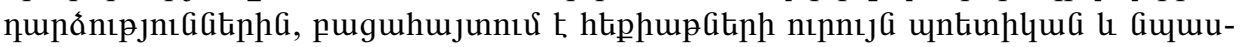

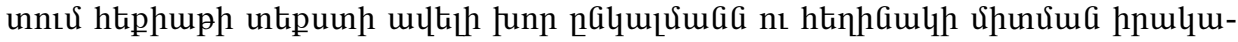
Gügưuan: 


\section{Интерпретация Метаморфозы как повествовательного приема в сказках Джорджа Макдональда}

Данная статья является попыткой исследовать метаморфозу как повествовательный прием в сказках детского шотландского писателя Джорджа Макдональда. В результате исследования теоретического материала и анализа примеров становится возможным описать метаморфозу как стилистический так и повествовательный прием. В этих сказках метаморфоза, придавая особый смысл описываемым событиям, выявляет уникальную поэтику сказок и способствует более глубокому пониманию текста сказок, тем самым реализуя намерение автора. 